\title{
Assessing continental-scale risks for generalist and specialist pollinating bee species under climate change
}

\author{
Stuart P.M. Roberts', Simon G. Potts', Koos Biesmeijer², Michael Kuhlmann², \\ Bill Kunin², Ralf Ohlemüller ${ }^{4}$
}

I Centre for Agri-Environmental Research, University of Reading, RG6 6AR, UK 2 Earth \& Biosphere Institute, IICB, Faculty of Biological Sciences, University of Leeds, Leeds LS2 9JT, UK 3 The Natural History Museum, Cromwell Road, London SW7 5BD, UK 4 School of Biological and Biomedical Sciences, and Institute of Hazard, Risk and Resilience, Durham University, South Road, Durham DH1 3LE, UK

Corresponding author: Stuart P.M. Roberts (s.p.m.roberts@reading.ac.uk)

Academic editor: Josef Settele | Received 30 March 2011 | Accepted 4 October 2011 | Published 19 December 2011

Citation: Roberts SPM, Potts SG, Biesmeijer K, Kuhlmann M, Kunin B, Ohlemüller R (2011) Assessing continentalscale risks for generalist and specialist pollinating bee species under climate change. BioRisk 6: 1-18. doi: $10.3897 /$ biorisk.6.1325

\begin{abstract}
Increased risks of extinction to populations of animals and plants under changing climate have now been demonstrated for many taxa. This study assesses the extinction risks to species within an important genus of pollinating bees (Colletes: Apidae) by estimating the expected changes in the area and isolation of suitable habitat under predicted climatic condition for 2050. Suitable habitat was defined on the basis of the presence of known forage plants as well as climatic suitability. To investigate whether ecological specialisation was linked to extinction risk we compared three species which were generalist pollen foragers on several plant families with three species which specialised on pollen from a single plant species. Both specialist and generalist species showed an increased risk of extinction with shifting climate, and this was particularly high for the most specialised species (Colletes anchusae and C. wolfi). The forage generalist C. impunctatus, which is associated with Boreo-Alpine environments, is potentially threatened through significant reduction in available climatic niche space. Including the distribution of the principal or sole pollen forage plant, when modelling the distribution of monolectic or narrowly oligolectic species, did not improve the predictive accuracy of our models as the plant species were considerably more widespread than the specialised bees associated with them.
\end{abstract}

\section{Keywords}

Colletes, bee, climate change, Europe, risk assessment, pollinator

Copyright Stuart P.M. Roberts et al. This is an open access article distributed under the terms of the Creative Commons Attribution License 3.0 (CC-BY), which permits unrestricted use, distribution, and reproduction in any medium, provided the original author and source are credited. 


\section{Introduction}

There is general consensus that the most pressing environmental problem that faces the world today is climatic change and it is widely acknowledged that this change is likely to have major impacts both on biodiversity (Green et al. 2003) and on human society in general (Stern 2007). Many animal and plant species are expected to show major shifts in abundance, distribution and phenology and this could lead to extinctions at the local, regional, continental or even global scale (Flenner and Sahlen 2008; Graham-Taylor et al. 2009; Hegland et al. 2009; Settele et al. 2008). Accurate prediction of likely risks under a shifting climatic regime is essential to enable conservation priorities to be set and assist in directing mitigation actions (Santos et al. 2009).

A number of recent studies have considered the effects of observed climatic shifts on various taxa, and in addition to more general studies such as Parmesan and Yohe (2003), Root et al. (2003) and Menzel et al. (2006), these include butterflies (Sparks and Yates 1997; Parmesan et al. 1999; Roy and Sparks 2000; Menéndez et al. 2008), flowering plants (Sparks et al. 2000) and birds (Sanz 2003; Sergio 2003). More recent work has used current distributions of European birds (Huntley et al. 2007) and butterflies (Schweiger et al. 2008; Schweiger et al. 2012; Settele et al. 2008) to forecast likely future ranges, and to consider the possible conservation implications of shifts in distributions.

In addition to work on butterflies, there are increasing numbers of studies on other insect groups, and these include Odonata (Dingemanse and Kalkmann 2008), Coleoptera (eg Molina-Montenegro et al. 2009), Diptera (eg Graham-Taylor et al. 2009), invertebrate disease vectors (e.g. Wilson and Mellor 2008) and pest species (e.g. Hoffmann et al. 2008). Among pollinators, Williams et al. (2007) have assessed the vulnerability of three species of bumblebee (Bombus) to extinction by studying climatic niches that determine their ranges at a regional scale.

The number of large scale multi-taxa studies on insect species other than Lepidoptera has been restricted because detailed data on the biology and distribution of most insects in general, and pollinator species in particular, are available at fine resolutions for only a few places. Risk of local extinctions can, therefore, be assessed quite accurately given detailed information on local population, habitat size and climatic conditions (e.g. Franzén et al. 2009). However, assessing extinction risks of these species at the regional, continental or global scale is hampered by lack of appropriate data.

A risk analysis should, ideally, be based on complete data on the species' distribution in conjunction with knowledge on both the abiotic requirements (e.g. climate, geomorphology, soil) and the biotic requirements (e.g. principal forage plants). Then, using scenarios for changes in climate and land use, a model can be built to predict potential range shifts and extinctions. Some existing studies have based their analyses on a climate only model (e.g. Huntley et al. 2007; Settele et al. 2008) and others (e.g. Luetolf et al. 2009) on a habitat only model. A smaller number of studies link both habitat and climate models (e.g. Santos et al. 2009; Schweiger et al. 2008; 2012). 
We make use of one of the few available pollinator datasets for which comprehensive European-scale distribution is currently known: a number of specialist and generalist Colletes bee species, some of which are endemic to Europe. We ask:

1) What are the levels of risk associated with shifts in climatic conditions at locations where the pollinator species currently occur?

2) Can we predict the current distribution of specialist and generalist pollinator species at a continental scale based on climate and host plant distribution variables?

3) Is it likely that the ranges of principal forage plants and specialist bees can become uncoupled under climate change with the possible threat of extinction to one or both species?

4) What are the likely future European distributions of the investigated species under the projected shifts in climatic conditions?

The aim of our study is to provide a continental-scale assessment of the risk a pollinator species is likely to face under future climate change and to determine if specialised species are at greater risk as a result of their narrow pollen forage requirements.

\section{Methods}

\section{Species distribution and climate data}

From a dataset containing distribution data on all 59 species of bees in the genus Colletes occurring in Europe (Kuhlmann, unpublished data) we selected six species for which there were sufficient data to cover adequately their entire European ranges (Appendix A). Three of these are polylectic species, i.e. pollen forage generalists (Colletes albomaculatus, C. impunctatus, C. nigricans) and three monolectic or narrowly oligolectic, i.e. forage specialists ( $C$. anchusae, C. hederae, C. wolfi). Pollen foraging in Colletes anchusae and C. wolfi is restricted to Cynoglottis barrelieri (Boraginaceae) (Müller and Kuhlmann 2003; 2008) whereas $C$. hederae generally restricts its foraging to Hedera helix (Araliaceae) (Schmidt and Westrich 1993; Bischoff et al. 2005), although occasionally it will forage for pollen at various Asteraceae if Hedera helix flowers are not available (Müller and Kuhlmann 2008; Westrich 2008). Distribution records of these species from the last 125 years (with 61\% of data from the last 40 years) across Europe were collated and transformed into a presence/absence map at 10' grid resolution. For the majority of $10^{\prime}$ grid cells, there was no record, but in total, 1,549 or $4.9 \%$ of all 10 ' grid cells had at least one record for one of the six species. Prevalence of the six species ranged from 10 to 150 occupied $10^{\prime}$ grid cells (Table 1). We have assumed that all records represent the current distribution (cf. Williams et al 2007). Although many areas have had poor coverage, the problem is reduced by mapping at a relatively coarse 10 ' resolution. The presence/absence matrix of these 1,549 grid cells was used to build distribution models of the species. 
Table I. Model specification and model fit. Percent variation of present-day distribution explained and model fit of distribution models for the six species.

\begin{tabular}{|c|c|c|c|}
\hline species & $\begin{array}{l}\text { number of 10' cells } \\
\text { recorded }\end{array}$ & model & $\begin{array}{l}\text { Percent variation in distri- } \\
\text { bution explained by model }\end{array}$ \\
\hline \multicolumn{4}{|l|}{ generalists } \\
\hline C. albomaculatus & 110 & climate & 31.7 \\
\hline C. impunctatus & 102 & climate & 64.2 \\
\hline C. nigricans & 150 & climate & 23.1 \\
\hline \multicolumn{4}{|l|}{ specialists } \\
\hline \multirow[t]{2}{*}{ C. anchusae } & \multirow[t]{2}{*}{16} & climate & 44.7 \\
\hline & & climate + hostplant & 45.5 \\
\hline \multirow[t]{2}{*}{ C. hederae } & \multirow[t]{2}{*}{76} & climate & 12.0 \\
\hline & & climate + hostplant & 12.2 \\
\hline \multirow[t]{2}{*}{ C. wolfi } & \multirow[t]{2}{*}{10} & climate & 65.0 \\
\hline & & climate + hostplant & 65.8 \\
\hline
\end{tabular}

Current (1961-1990 average) and future (2041-2050 average, henceforth "2050") climate conditions at the same resolution were taken from Mitchell et al. (2004) and we used the following five climate variables to predict the distribution of our target species: mean annual temperature, mean minimum temperature of the coldest months, mean annual precipitation, annual water deficit and growing degree days $>$ $5^{\circ} \mathrm{C}$. These variables represent a set of biologically meaningful factors which, given the lack of detailed knowledge of climate requirements of individual species, aims to cover the relevant climate conditions for our six species. We restrict our analyses to a low greenhouse gas emission scenario (B2) which represents a socio-economic storyline focussing on local and regional solutions to economic and environmental problems and projects a global average temperature increase by the end of this century of between 1.4 and $3.8^{\circ} \mathrm{C}$ (IPCC 2007). We use this as a best case scenario of the lowest risk so that these underpin the minimum conservation action responses.

The known distribution (both historic and current) of the genus Cynoglottis is mapped in Müller \& Kuhlmann (2003) who based the map on a synthesis of various regional, national and European floras (see references therein). The known distribution of Hedera helix is mapped by Meusel (1978) modified by Kuhlmann et al. (2007). All distributions were digitised as shape files in ArcGIS and converted to a presence/ absence grid at the same resolution as the climate grid.

\section{Distribution modelling}

Generalised Linear Models (GLMs) with binomial errors and with linear and quadratic terms for all variables were used to predict the current distribution of the Colletes species. For the generalist species, we predicted their current distributions across Europe based on all six climate variables, while for the specialist species, we used the six 
climate variables plus the host plant distribution as a binary predictor variable. For all models, we compared the model fit between the full model (including all possible predictor variables) and the most parsimonious minimal adequate model (including only the most significant variables retained after stepwise variable selection allowing for addition and deletion of variables at each step). The difference in model fit between the two methods was generally small and so we present the outcomes of the full models. All models and variable selection procedures were performed in S-Plus 6.2. Predictive power of the full model was assessed by quantifying the percentage of variation in species presence/absence explained by the full set of variables (Table 1). We used the models fitted on the current climate data to predict climatic suitability of the six species under future (2050) climate conditions. For the three specialist species, we assumed that the distribution of the host plants will not change substantially between now and 2050 seeing that the species are almost ubiquitous in Europe. Comparing current observed, current modelled and future modelled distributions of the six species allows us to assess likely shifts in suitable climate space under changing climate conditions. For each species we compare the local (within a $100 \mathrm{~km}$ radius from each observed location) and continental-wide change in climatically suitable area between current and future climate conditions (Fig. 1).

\section{Results}

\section{Current distributions and suitable climate space}

Within the genus Colletes, we have selected six species with a well recorded European distribution. We were able to explain between 12\% (C. hederae) and 65\% (C. wolf) of the variation in their current distribution with the climate variables chosen here (Table 1). Overall, our bioclimate models were able to reproduce the observed current European distribution of our species accurately (Table 1; Fig. 1a-f). In particular, the suitable climate space of the two southern European generalist species $C$. albomaculatus and $C$. nigricans, for instance, was captured very well by our models. When modelling the distribution of the specialist species, including the distribution of the principal forage plants as an additional predictor, does not improve the model fit of the models. The percent variation in distribution with the food plants included in the model only increases very slightly (Table 1). C. impunctatus (Fig. 1b), shows that it occurs in most of its current suitable climate space, occurring in the clearly defined boreal climatic area in northern Europe, with a second centre of distribution in the montane region of the Alps in the south. Colletes hederae, on the other hand, appears to be the species which has least filled its suitable climatic space (Fig. 1e). Large areas in Italy, France and Spain have highly suitable climate but no, or only few, occurrences of the species have thus far been reported.

Under present-day climate conditions, species with a predominantly Mediterranean distribution are occupying areas with the highest climatic rarity, i.e., the climatic 


\section{Present-day recorded distribution}

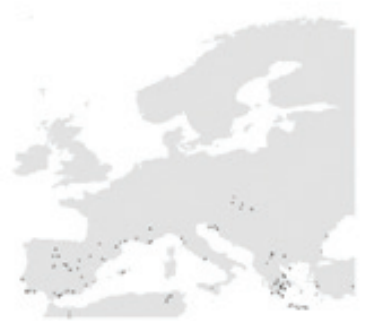

a

\section{C. albomaculatus}

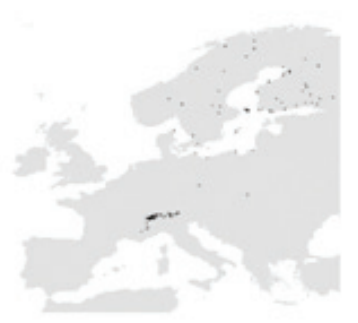

b

\section{C. impunctatus}

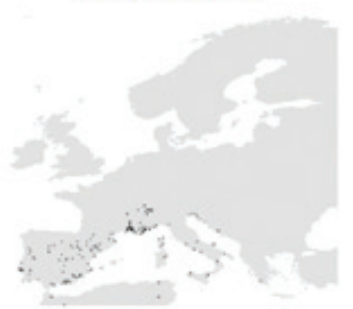

\section{Present-day modelled} climatic suitability
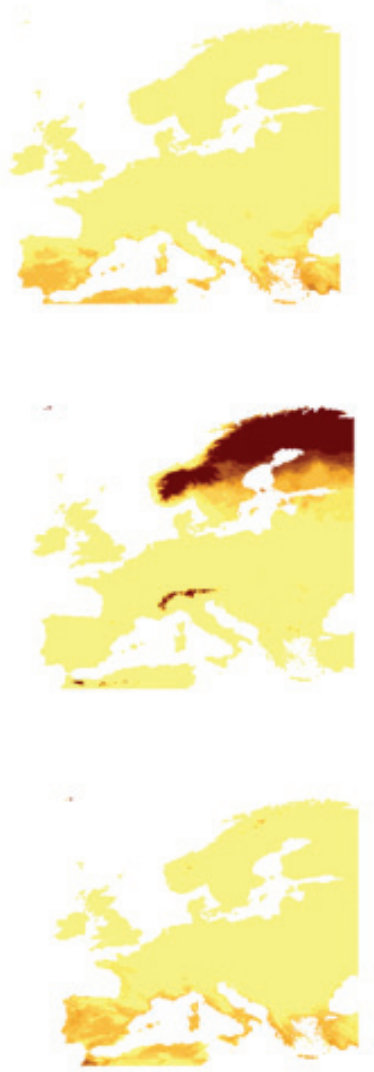

2050 modelled

climatic suitability

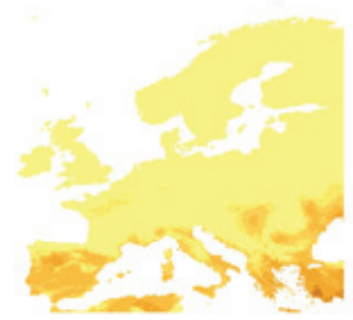

c

\section{C. nigricans}

Figure I (a-c). Potential future European distribution of three investigated generalist Colletes species based on climate. [Present day recorded distribution; present day modelled distribution, and 2050 modelled climatic suitability of a Colletes albomaculatus b C. impunctatus and c C. nigricans]

conditions of the locations where the species is currently found are not found in many areas elsewhere in Europe. C. nigricans, with a south-western Mediterranean distribution, has the rarest suitable climate envelope of our six species (Fig. 1c). C. albomaculatus, which exploits suitable climatic space more widely across the Mediterranean region, extends into south eastern Europe (Fig. 1a).

\section{Future suitable climate space}

We calculated the change in climatically suitable area for each species between current and future climatic conditions locally (within a $100 \mathrm{~km}$ radius) and Europe- 


\section{Present-day recorded distribution}

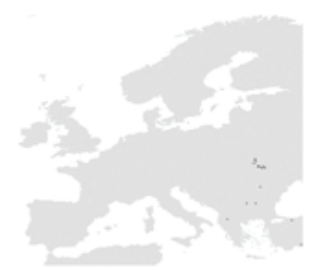

d

\section{Present-day recorded distribution}

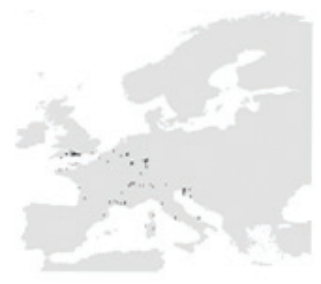

e

\section{C. hederae}

Figure I (d-e). Potential future European distribution of two investigated specialist Colletes species based on climate and host plant distribution. [Present day recorded distribution; present day modelled suitability (climate); present day modelled suitability (climate $\&$ hostplant); 2050 modelled suitability (climate); and 2050 modelled suitability (climate $\&$ hostplant) of $\mathbf{d}$ Colletes anchusae and $\mathbf{e} C$. hederae]

\section{0 modelled suitability (climate)}

2050

modelled suitability (climate+hostplant)

2050 modelled suitability (climate)

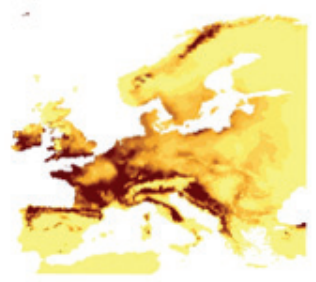

2050

modelled suitability (climate+hostplant)
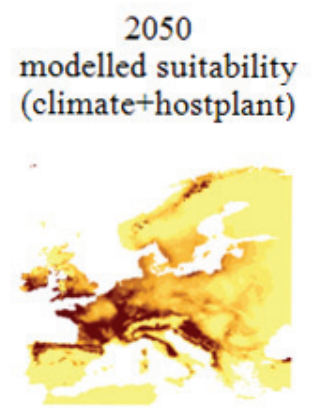
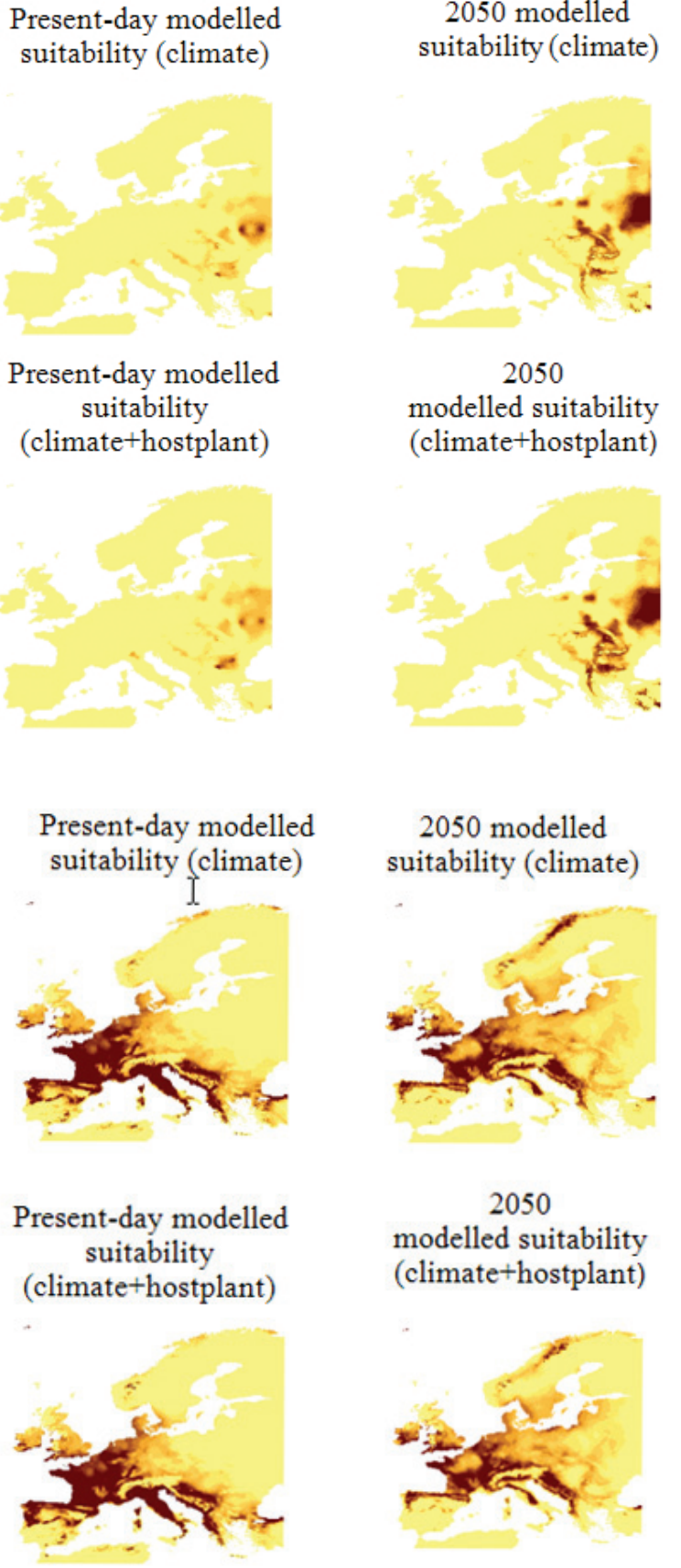
Present-day modelled suitability (climate+hostplant)

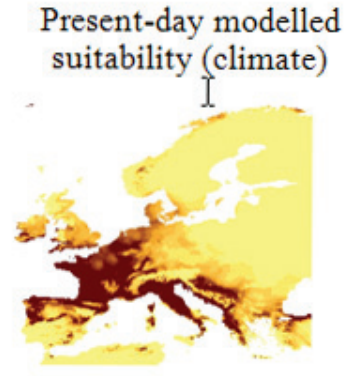



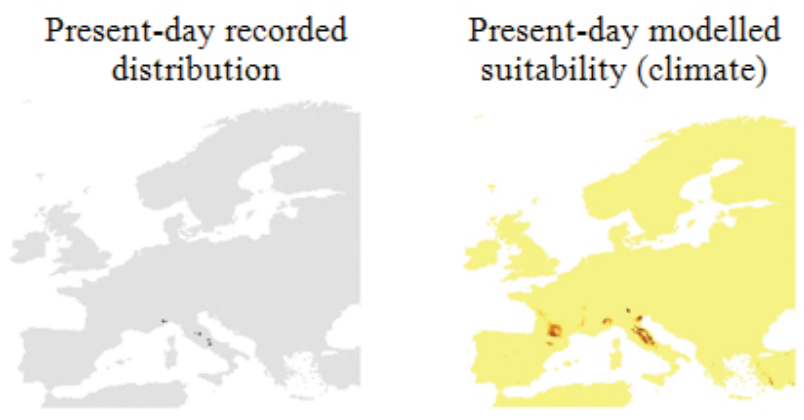
Present-day modelled suitability (climate+hostplant)

\section{f C. wolfi}

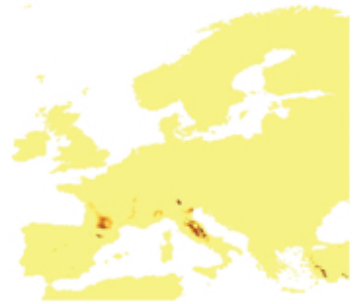

2050 modelled

suitability (climate)

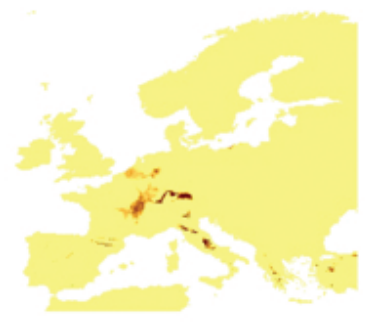

2050

modelled suitability (climate+hostplant)

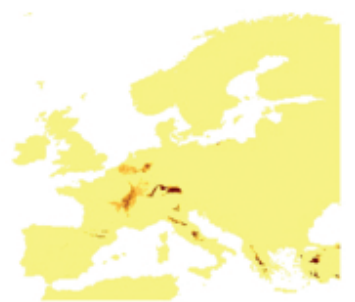

Figure I (f). Potential future European distribution of the specialist Colletes wolf based on climate and host plant distribution. [Present day recorded distribution; present day modelled suitability (climate); present day modelled suitability (climate \& hostplant); 2050 modelled suitability (climate); and 2050 modelled suitability (climate $\&$ hostplant)]

wide. Plotting the two against each other allows us to assess which species are going to be affected by loss of climatically suitable area locally vs. at the continental scale (Fig. 2). For instance, for C. impunctatus (generalist), close to $100 \%$ of grid cells with $100 \mathrm{~km}$ radius of current occurrences and in Europe as a whole are predicted to become less climatically suitable for that species in 2050 than they are now. This species is therefore likely to face difficulties locally where it currently occurs but also in terms of finding new areas to colonise in Europe. For C. wolf (specialist) on the other hand, over $70 \%$ of grid cells locally are predicted to become climatically less suitable between now and 2050, where in the rest of Europe only less than $10 \%$ of grid cells in Europe will be less suitable for this species than they are now. This indicates that this species is likely to face difficulties locally, however, if it manages to disperse and migrate beyond its local environment, there are large areas elsewhere in Europe that will be climatically suitable in 2050 . For the other two specialist species (C. anchusae, $C$. hederae), only ca. $20 \%$ of grid cells both close to where the species are currently found and Europe-wide are predicted to become less climatically suitable. This indicates that these species should be able to find suitable climatic conditions locally as well as farther afield (Figs 1d-e, 2). 


\section{Proportion of grid \\ cells with decreasing climatic suitability within Europe}

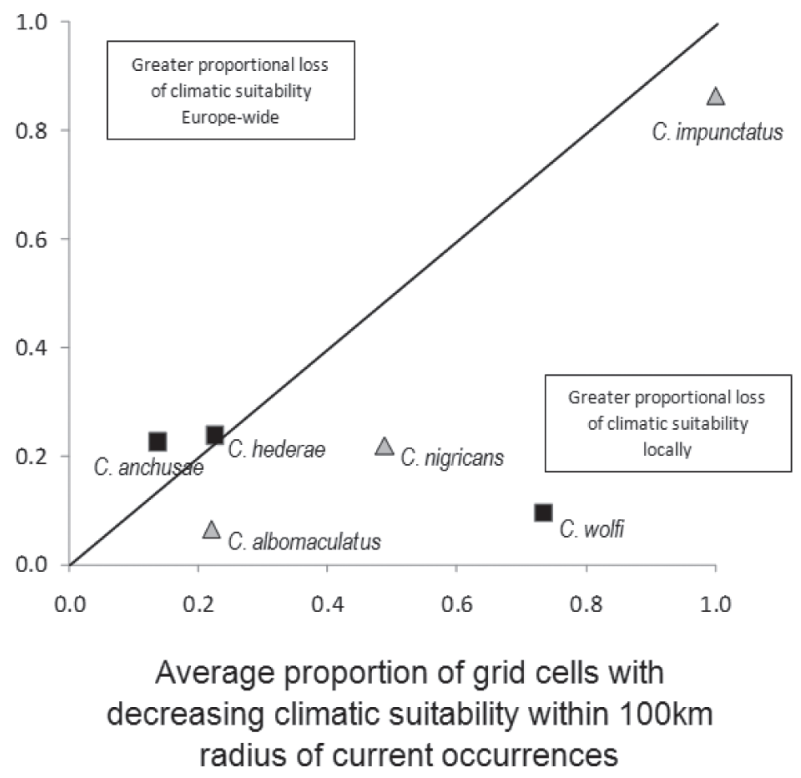

Figure 2. Local vs. continental scale change in climatic suitability between current and future climatic suitability of six Colletes species. For each species, we calculated the average number of grid cells within a $100 \mathrm{~km}$ radius that show decreasing climatic suitability for the species between current and future conditions. We also calculated for each species the proportion of grid cells with decreasing climatic suitability for the species in the whole of Europe. Black squares indicate specialists, grey triangles indicate generalists. The solid line indicates the 1:1 line.

\section{Discussion}

There are threats to all six studied Colletes species under predicted climate change, but the threats are not related to forage plant specialisation. In general, we predict that the trends will be towards a decrease in overall range of our species in Europe caused by a combination of a reduction in suitable climatic space, compounded by an increase in isolation between climatically suitable areas. The addition of principal forage plant distribution as an additional predictor, however, does not improve the power of the models, as the specialist forage plants are very widely distributed across the continent. This reflects findings by Schweiger et al. (2012) who found that the majority of investigated butterfly species in Europe are not limited by their larval host plants.

Of the generalist species, those currently showing a predominantly southern European distribution are predicted to exhibit only relatively minor decreases (C. nigricans) or no decrease in climatically suitable area (C. albomaculatus) under climate change. Both species, however, are predicted to experience an increase in isolation of their future suitable climate space. These changes may appear relatively small, but they represent net changes, and there is a clear movement northwards of the future climatic space, away from the current centres of distribution. C. nigricans, already well 
established in the Mediterranean areas of France, may be able to expand into much of central and northern France along major river valleys. The projected situation in the drier parts of its current range suggests future significant declines in southern Iberia. The predicted suitable climatic envelope maps (Fig. 1a-f) suggest that C. albomaculatus looks well positioned to be able to expand into eastern central Europe, and possibly also in the steppic environments to the north west of the Black Sea (for map of European biogeographic regions see Appendix B). In both cases, expansion of range would be aided by their ability to exploit a broad diet spectrum.

Colletes impunctatus is a member of the Boreo-Alpine element in the European bee fauna, and is the generalist species that appears to be under the greatest threat from projected climate change. The area suitable for this species will be severely reduced in the Alps (currently a stronghold), and disjunctions will appear in Fennoscandia. These reductions in area will negatively affect this species.

The two restricted species which are monolectic on Cynoglottis barrelieri, (Colletes anchusae and $C$. wolfi) appear to be at risk from both a reduction in suitable climatic space as well as increased isolation (Fig. 1d, f). This is particularly significant for $C$. anchusae, which moves from being a species with a relatively low risk of negative climatic impacts, to one with a high risk. C. wolf is currently very restricted in range and has a disjunct bicentric distribution, with centres in central Italy and again in the north of that country. This study indicates that the northern Italian population is under severe threat, with the suitable climatic envelope being eliminated by 2050, with distance, coupled with topography (the Alps and Appenine mountains acting as a dispersal barrier), making colonisation of new areas unlikely.

The third specialist species, Colletes hederae (Fig. 1e), might derive some benefits from the projected changes in climate. $C$. hederae is widely distributed in much of lowland western Europe, and is the most widespread of the specialist species. It is postulated that the species has expanded from centres south of the Alps with ameliorating climate (Kuhlmann, unpublished data). $C$. hederae has undergone a very rapid expansion of range in the last twelve years, reaching The Netherlands in 1997 (Peeters et al. 1999), and both Luxembourg (Feitz 2001) and the UK in 2001 (Cross 2002). The range has also expanded eastwards across northern Switzerland and southern Germany (Herrmann 2007) into central Germany (Frommer 2008). The principal forage plant, Hedera helix, is known to be strongly climate limited. Iversen (1944) demonstrated that the plant reproduces vegetatively in the northern parts of its range and that flowering is associated with areas of greater warmth. The northern boundaries of flowering of Hedera helix are likely to move northwards, creating new colonisation opportunities for Colletes hederae in the future.

We can say with confidence that although projected climate change may, in part, negatively impact on the studied bee species, it is most unlikely that declining populations of the most specialised Colletes will cause a serious reduction in pollination services to the principal forage plants. Waser et al. (1996) demonstrated that specialist pollinators tend to pollinate generalist plants, and this is certainly the case for Hedera helix (Ollerton et al. 2007) which attracts a wide range of insect visitors from several 
orders. No data is available on the species that visit Cynoglottis barrelieri, but the flowers of the related plant Anchusa strigosa are known to attract a diverse assemblage of long-tongued bees of the genera Eucera and Anthophora in Israel (Kadmon and Shmida 1992) and so it is likely that $C$. barrelieri also attracts species other than $C$. anchusae and C. wolfi as visitors.

One of the possible consequences for both generalist and specialist Colletes species under climate change is that future shifts in range and distribution may be accompanied by changes in abundance. Colletes are known to support a number species of brood parasitic bees in the genus Epeolus which specialise on Colletes (Westrich 1989; Amiet et al. 1999) and future shifts are particularly likely to affect brood parasites, which need well established host populations to support them. In the case of $E$. alpinus, whose host (C. impunctatus (Amiet et al. 1999)) is restricted to boreo-alpine habitats, these risks are likely to be greater as the host habitats are predicted to diminish in area. Of our other modelled species, Colletes hederae is cited as a host of Epeolus cruciger (Kuhlmann et al. 2007), and believed to be a host of E. fallax (P. Westrich pers. comm.). In populations of $C$. hederae in northern Italy, Slovenia and southern Switzerland, nests are subject to parasitism by the bee E. cruciger, whereas no parasitism has been noted away from these core areas (Kuhlmann et al. 2007). Changing climate appears to have allowed the $C$. hederae to expand rapidly, without the cleptoparasite following at present.

Climate change presents a number of challenges for conservation. To the bees themselves, the plants they visit, and pollination services in general. In order to understand how climate shifts may affect plants and pollination more generally, a wider ranging study would be necessary, as this work deals with only 6 species out of an estimated European bee fauna of about 2,250 species (Polaszek 2004). However, given the likely loss of suitable climatic space and increased isolation of areas for these six species, it is likely that many other European bees may also be subject to similar increases in extinction risk under climate change. For effective bee conservation under environmental change, it is necessary to ensure that as the suitable climate envelopes move, that suitable habitat is available for the bees to exploit. For those bees that are forage specialists, this will clearly also involve the provision of the specialised forage itself.

\section{Acknowledgements}

We thank the suppliers of bee distribution data across Europe, including the Bees, Wasps \& Ants Recording Society (UK), Øistein Berg (Norway), EIS (Netherlands), Jaan Luig (Estonia), Vergilijus Monsevičius (Lithuania), Guy Söderman (Finland), Fritz Gusenleitner (Austria). The authors acknowledge the European Environment Agency (http://www.eea.europa.eu) for making available their 2005 map of Europe's Biogeographical regions with national boundaries.

This study is part of two Europe-wide assessments of the risks associated with pollinator loss and its drivers, undertaken within the FP 6 Integrated Project "ALARM" 
(Assessing LArge scale environmental Risks for biodiversity with tested Methods: GOCE-CT-2003-506675; www.alarmproject.net; Settele et al. 2005) and the FP 7 Collaborative Project STEP (Status and Trends of European Pollinators; www.stepproject.net; Potts et al. 2011).

\section{References}

Allouche O, Tsoar A, Kadmon R (2006) Assessing the accuracy of species distribution models: prevalence, kappa and the true skill statistic (TSS). Journal of Applied Ecology 43: $1223-1232$.

Amiet F, Müller A, Neumeyer R (1999) Fauna Helvetica 4: Apidae 2. Centre Suisse de Cartographie de la Faune.

Bischoff I, Eckelt E, Kuhlmann M (2005) On the Biology of the Ivy-Bee Colletes hederae Schmidt \& Westrich, 1993 (Hymenoptera, Apidae) Bonner Zoologische Beitrage 53 (Heft 1/2): 27-36.

Cross IC (2002) Colletes hederae Schmidt \& Westrich (Hym., Apidae) new to mainland Britain with notes on its ecology in Dorset. Entomologists Monthly Magazine 138-1660: 201-204.

Dingemanse NJ, Kalkman VJ (2008) Changing temperature regimes have advanced the phenology of Odonata in the Netherlands. Ecological Entomology 33: 394-402.

Feitz F (2001) Découverte de Colletes hederae Schmidt \& Westrich, 1993 (Hymenoptera, Colletidae) au Luxembourg. Bulletin de la société des naturalistes luxembourgeois 102: 87-90.

Fielding AH, Bell JF (1997) A review of methods for the assessment of prediction errors in conservation presence/absence models. Environmental Conservation 24: 38-49.

Flenner I, Sahlen G (2008) Dragonfly community re-organisation in boreal forest lakes: rapid species turnover driven by climate change? Insect Conservation and Diversity 1: 169-179.

Franzén M, Larsson M, Nilsson SG (2009) Small local population sizes and high habitat patch fidelity in a specialised solitary bee. Journal of Insect Conservation 13: 89-95.

Frommer U (2008) Grundlagen der Ausbreitung und aktuellen nördlichen Verbreitung der Efeu-Seidenbiene Colletes hederae Schmidt \& Westrich, 1993 in Deutschland (Hymenoptera: Apidae). Mitteilungen des Internationalen Entomologischen Vereins 33: 59-74.

Graham-Taylor LG, Stubbs AE, Brooke MD (2009) Changes in phenology of hoverflies in a central England garden. Insect Conservation and Diversity 2: 29-35.

Green RE, Harley M, Miles L, Scharlemann J, Watkinson A, Watts O (Eds) (2003) Global Climate Change and Biodiversity. University of East Anglia.

Hegland SJ, Nielsen A, Lazaro A, Bjerknes A-L, Totland Ø (2009) How does climate warming affect plant-pollinator interactions? Ecology Letters 12: 184-195.

Herrmann M (2007) Ausbreitungswelle der Efeu-Seidenbiene (Colletes hederae) in BadenWürttemberg (Hymenoptera, Apidae) und die Erschließung eines ungewöhnlichen Nisthabitates. Mitteilungen des Entomologischen Vereins, Stuttgart 42: 96-98.

Hoffmann AA, Weeks AR, Nash MA, Mangano GP, Umina PA (2008) The changing status of invertebrate pests and the future of pest management in the Australian grains industry. Australian Journal of Experimental Agriculture 48: 1481-1493. 
Huntley B, Green R, Collingham Y, and Willis SG (2007) A Climatic Atlas of European Breeding Birds. Lynx Edicions, 521 pp.

Iversen J (1944) Viscum, Hedera and Ilex as climatic indicators. A contribution to the study of past-glacial temperature climate. Geologiska Föreningens i Stockholm Förhandlingar 66: 463-483.

IPCC (2007) Summary for Policymakers. In: Solomon S, Qin D, Manning M, Chen Z, Marquis $M$ et al. (Eds) Climate Change (2007) The Physical Science Basis. Contribution of Working Group I to the Fourth Assessment Report of the Intergovernmental Panel on Climate Change. Cambridge University Press, Cambridge, United Kingdom and New York, NY, USA.

Kadmon R, Shmida A (1992) Departure rules used by bees foraging for nectar - a field test. Evolutionary Ecology 6: 142.

Kuhlmann M, Else GR, Dawson A and Quicke DLJ (2007) Molecular, biogeographical and phenological evidence for the existence of three western European sibling species in the Colletes succinctus group (Hymenoptera: Apidae). Organisms, Diversity and Evolution 7: $155-165$.

Luetolf M, Guisan A, Kienast F, (2009) History Matters: Relating Land-Use Change to Butterfly Species Occurrence. Environmental Management 43: 436-446.

Luoto M, Poyry J, Heikkinen RK, Saarinen K (2005) Uncertainty of bioclimate envelope models based on the geographical distribution of species. Global Ecology and Biogeography $14: 575-584$.

McPherson JM, Jetz W, Rogers DJ (2004) The effects of species' range sizes on the accuracy of distribution models: ecological phenomenon or statistical artefact? Journal of Applied Ecology 41: 811-823.

Menéndez R, González-Megías A, Lewis OT, Shaw MR, Thomas CD (2008) Escape from natural enemies during climate-driven range expansion: a case study. Ecological Entomology 33: 413-421.

Menzel A, Sparks TH, Estrella N, Koch E, Aasa A et al. (2006) European phenological response to climate change matches the warming pattern. Global Change Biology 12: 1969-1976.

Meusel H (Ed) (1978) Vergleichende Chorologie der Zentraleuropäischen Flora, Bd. II. Fischer, Jena.

Mitchell TD, Carter TR, Jones PD, Hulme M, New M (2004) A comprehensive set of highresolution grids of monthly climate for Europe and the globe: the observed record (19012000) and 16 scenarios (2001-2100). Tyndall Centre Working Paper 55.

Molina-Montenegro M, Briones R, Cavieres LA (2009). Does global warming induce segregation among alien and native beetle species in a mountain-top? Ecological Research 24: 31-36.

Müller A, \& Kuhlmann M (2003) Narrow flower specialization in two European bee species of the genus Colletes (Hymenoptera: Apoidea: Colletidae). European Journal of Entomology 100: 631-635.

Müller A, \& Kuhlmann M (2008) Pollen hosts of western Palaearctic bees of the genus Colletes (Hymenoptera: Colletidae): the Asteraceae paradox. Biological Journal of the Linnean Society 95: 719-733. 
Ohlemüller R, Gritti ES, Sykes MT, Thomas CD (2006) Towards European climate risk surfaces: the extent and distribution of analogous and non-analogous climates 1931-2100. Global Ecology and Biogeography 15: 395-405.

Ollerton J, Kilick A, Lamborn E, Watts S, Whiston M (2007) Multiple meanings and modes: on the many ways to be a generalist flower. Taxon 56: 717-728.

Parmesan C, Yohe G (2003) A globally coherent fingerprint of climate change impacts across natural systems. Nature 421: 37-42.

Parmesan C, Ryrholm N, Stefanescu C, Hill JK, Thomas CD, et al. (1999) Poleward shifts in geographical ranges of butterfly species associated with regional warming. Nature 399: 579-583.

Pearson RG, Raxworthy CJ, Nakamura M, Peterson AT (2007) Predicting species' distributions from small numbers of occurrence records: a test case using cryptic geckos in Madagascar. Journal of Biogeography 34: 102-117.

Peeters TMJ, Raemakers IP, Smit J (1999) Voorlopige atlas van de Nederlandse bijen (Apidae). European Invertebrate Survey-Nederland, Leiden.

Polaszek A (2004) Fauna Europaea: Apidae. In Noyes J (Ed) (2004) Fauna Europaea: Hymenoptera: Apidae. Fauna Europaea version 1.1, http://www.faunaeur.org

Potts SG, Biesmeijer JC, Bommarco R, Felicioli A, Fischer M, Jokinen P, Kleijn D, Klein AM, Kunin WE, Neumann P, Penev LD, Petanidou T, Rasmont P, Roberts SPM, Smith HG, Sørensen PB, Steffan-Dewenter I, Vaissière BE, Vilà M, Vujić A, Woyciechowski M, Zobel M, Settele J, Schweiger O (2011) Developing European conservation and mitigation tools for pollination services: approaches of the STEP (Status and Trends of European Pollinators) project. Journal of Apicultural Research 50: 152-164.

Root TL, Price JT, Hall KR, Schneider SH, Rosenzweig C et al. (2003) Fingerprints of global warming on wild plants and animals. Nature 421: 57-60.

Roy DB \& Sparks TH (2000) Phenology of British butterflies and climate change. Global Change Biology 6: 407-416.

Santos X, Brito JC, Caro J, Abril AJ, Lorenzo M et al. (2009) Habitat suitability, threats and conservation of isolated populations of the smooth snake (Coronella austriaca) in the southern Iberian Peninsula. Biological Conservation 142: 344-352.

Sanz JJ (2003) Large scale effects of climate change on breeding parameters of pied flycatchers in Western Europe. Ecography 26: 45-50.

Schmidt K, \& Westrich P (1993) Colletes hederae n.sp., eine bisher unerkannte auf Efeu (Hedera) spezialisierte Bienenart (Hymenoptera: Apoidea). Entomologische Zeitschrift 103(6): 89-112.

Schweiger O, Settele J, Kudrna O, Klotz S, Kühn I (2008) Climate change can cause spatial mismatch of trophically interacting species. Ecology 89: 3472-3479.

Schweiger O, Heikkinen RK, Harpke A, Hickler T, Klotz S, Kudrna O, Kühn I, Pöyry J, Settele $\mathrm{J}$ (2012) Increasing range mismatching of interacting species under global change is related to their ecological characteristics. Global Ecology and Biogeography 21 (1): 88-99.

Sergio F (2003) Relationship between laying dates of black kites Milvus migrans and spring temperatures in Italy: rapid response to climate change? Journal of Avian Biology 34: 144-149. 
Settele J, Hammen V, Hulme P, Karlson U, Klotz S, Kotarac M, Kunin W, Marion G, O'Connor M, Petanidou T, Peterson K, Potts S, Pritchard H, Pysek P, Rounsevell M, Spangenberg J, Steffan-Dewenter I, Sykes M, Vighi M, Zobel M, Kühn I (2005): ALARM - Assessing LArge-scale environmental Risks for biodiversity with tested Methods. Gaia - Ecological Perspectives for Science and Society 14: 69-72.

Settele J, Kudrna O, Harpke A, Kühn I, van Swaay C, Verovnik R, Warren M, Wiemers M, Hanspach J, Hickler T, Kühn E, van Halder I, Veling K, Vliegenthart A, Wynhoff I, Schweiger O (2008) Climatic Risk Atlas of European Butterflies. BioRisk 1: 1-712. doi: 10.3897/biorisk.1

Sparks TH, Jeffree EP, Jeffree CE (2000) An examination of the relationship between flowering times and temperature at the national scale using long-term phenological records from the UK. International Journal of Biometeorology 44: 82-87.

Sparks TH, Yates TA (1997) The effect of spring temperature on the appearance dates of British butterflies 1883-1993. Ecography 20: 368-374.

Stern NH (2007) The Economics of Climate Change: The Stern Review. Great Britain Treasury; Cambridge University Press.

Waser N, Chittka L, Price MV, William NM, Ollerton J (1996) Generalization in pollination systems, and why it matters. Ecology 77: 1043-1060.

Westrich P (2008) Flexibles Pollensammelverhalten der ansonsten streng oligolektischen Seidenbiene Colletes hederae Schmidt \& Westrich (Hymenoptera: Apidae). Eucera, Beiträge zur Apidologie 1. Heft 2: 17-32.

Westrich P (1989) Die Bienen Baden-Württembergs. Vol. 1., Ulmer Verlag, Stuttgart, 431 pp. Williams PH, Araujo MB, and Rasmont P (2007) Can vulnerability among British bumblebee (Bombus) species be explained by niche position and breadth? Biological Conservation 138: 493-505.

Wilson A, Mellor P (2008) Bluetongue in Europe: vectors, epidemiology and climate change. Parasitology Research 104: 489. 


\section{Appendix A}

Summary data at 10' grid cell resolution (UTM WGS84) used for mapping the 6 species of Colletes in this study

Abbreviations used:

$\begin{array}{ll}\text { alb } & \text { Colletes albomaculatus } \\ \text { anc } & \text { Colletes anchusae } \\ \text { hed } & \text { Colletes hederae } \\ \text { imp } & \text { Colletes impunctatus } \\ \text { nig } & \text { Colletes nigricans } \\ \text { wol } & \text { Colletes wolfi }\end{array}$

For further information on the dataset, contact M. Kuhlmann.

\begin{tabular}{|c|c|c|c|c|c|c|c|}
\hline alb & & & & & & & \\
\hline 29RMP46 & 29RPQ56 & 29SMC68 & 29SMC78 & 29SNA09 & 29SNB00 & 29SNB01 & 29SNB10 \\
\hline 29SNB20 & 29SNB40 & 29SNB51 & 29SNB90 & 29SPB10 & 30RYP76 & 30STB32 & 30STB53 \\
\hline 30SUB31 & 30SUB51 & 30 SUB60 & 30 SUB69 & 30SUF08 & $30 S U F 44$ & 30 SUF65 & 30SVA86 \\
\hline 30 SVC56 & 30SVD63 & 30SVG10 & 30SVG42 & 30SVG80 & 30SVK72 & 30SVK82 & 30SWF09 \\
\hline 30SWJ92 & 30SXG39 & 30SYH14 & 30TTK96 & 30TUK17 & 30TUM00 & 30TUM39 & 30TUM51 \\
\hline 30TVK09 & 30TVK39 & 30TVK47 & 30TWK53 & 30TWL64 & 30TXM71 & 31SED17 & 31SED39 \\
\hline 31 TBF96 & 31ТВН77 & 31TCF24 & 31TDH52 & 31 TDH87 & 31TEH95 & 31TEJ40 & 31TFJ54 \\
\hline 32SME66 & 32SME69 & 32 SMF72 & 32SNF03 & 32TKN98 & 32TLN08 & 32TLP00 & 32 TLP10 \\
\hline 32TLQ07 & 32TPN59 & 32ТРP14 & 33 SVB35 & 33TUF66 & 33TVK28 & 33TVK39 & 33TYN17 \\
\hline $33 \mathrm{UXP} 35$ & $33 \mathrm{UXQ} 42$ & 34 SEF68 & 34 SEG56 & 34SEH92 & 34 SFF49 & 34 SFF75 & 34 SFF83 \\
\hline 34 SFG20 & 34 SFG56 & 34 SFG 57 & 34 SFG65 & 34 SFG66 & 34SFG93 & 34 SFH26 & 34 SFH29 \\
\hline 34 SFH60 & 34SFH81 & 34 SFJ76 & 34SGE61 & 34SGG15 & $34 \mathrm{SGH} 26$ & 34SGH44 & 34 SGH52 \\
\hline 34SGJ03 & 34SGJ14 & 34TCS18 & 34TCT54 & 34TCT56 & 34TEL01 & 34TEL47 & 34TEM53 \\
\hline 34TEM61 & 34TFM90 & 34TGK34 & 35SKC30 & 35SKV43 & 35SKV61 & 35SLB30 & 35SLU09 \\
\hline 35SLU98 & 35 SLV40 & 35SLV80 & 35SMA96 & $35 \mathrm{SNB} 27$ & $35 \mathrm{SNC} 15$ & 35TNG67 & 35 TNH52 \\
\hline 35 TPJ27 & 36RYA43 & 36SUG87 & 36SVG59 & 36SWG14 & 36SXG44 & 36SXH11 & 36SXH69 \\
\hline 36SXH95 & 36SXJ84 & 36TWL53 & 36TWQ43 & 36TWR20 & 36TWR91 & 36TXQ15 & 36TXQ28 \\
\hline 36TYL30 & 37SBR69 & 37SCE71 & 37SED09 & 37SED78 & 37SFD01 & 37 SFD90 & 37TCL02 \\
\hline 37TEE37 & 37TFE68 & 37TGE16 & 37TGE19 & 37TGE59 & 37TGF12 & 38SLH56 & 38SLJ39 \\
\hline 38SLJ91 & 38SMG43 & 38SMH02 & 38TKK84 & 38TMK44 & 38TMK55 & 39STC68 & 39 STD50 \\
\hline 39SWV85 & 39SXV17 & 39TTG75 & 42SVJ72 & & & & \\
\hline \multicolumn{8}{|l|}{ anc } \\
\hline $34 \mathrm{TCS} 18$ & 34TDL83 & 34TGN08 & 35TLH39 & 35TLL95 & 35ULP69 & 35ULP79 & 35ULP89 \\
\hline 35 ULQ25 & 35ULQ47 & 35ULR41 & 35ULR42 & 35UMP08 & 35UMP39 & 35 UMP47 & 36SUG90 \\
\hline 36SWG14 & 36SXG41 & 36 SXH47 & 36SXH67 & 36SYG15 & 36TTL81 & 37SCE91 & 37SED08 \\
\hline \multicolumn{8}{|l|}{ hed } \\
\hline 30TXR38 & 30TYQ02 & 30UVA46 & 30UVB91 & 30UVU29 & 30UWA49 & 30UWB01 & 30UWB30 \\
\hline 30UWB36 & 30UWB40 & 30UWB41 & 30 UWB50 & 30UWB51 & 30UWB52 & 30 UWB60 & 30UWB61 \\
\hline 30UWB70 & 30UWB71 & 30UWB72 & 30UWB74 & 30UWB81 & 30UWB82 & 30UWB92 & 30 UWV00 \\
\hline 30UWV27 & 30UWV37 & 30UWV38 & 30UWV47 & 30UWV48 & 30UWV64 & 30UWV65 & 30UWV97 \\
\hline
\end{tabular}




\begin{tabular}{|c|c|c|c|c|c|c|c|}
\hline $30 \mathrm{UXB} 42$ & 1TDG56 & 31 TEJ25 & 31 TEJ68 & 31TFJ06 & $31 \mathrm{TFJ} 34$ & 31TFJ85 & 31 TFJ95 \\
\hline 31 TFJ96 & 31 TFL50 & 31 UCS23 & 31 UCS33 & 31UDR06 & 31UDR91 & 31UES58 & 31 UFS10 \\
\hline 31UFS82 & UFS83 & 1 UFS93 & 32TKS61 & 2 TKS62 & 32 TKS96 & 32TLS16 & 32TLS18 \\
\hline 32 TLS72 & TMK49 & TMS12 & 2 TMS93 & 2TNK35 & 32 TNM46 & 32TNR29 & 32ТРМ59 \\
\hline 32 ТРP24 & 2 TPS67 & 32 TPS75 & 32ULU92 & 32ULV08 & 32ULV09 & 32UMA23 & 32UMA51 \\
\hline 32UMA52 & 2UMA54 & 32UMV39 & 32 UMV43 & 32UMV49 & 32 UMV62 & 33TUG02 & 33TUK99 \\
\hline 33TUL93 & TUL97 & 33TVK76 & 33TVL07 & 33TVL14 & 33TVL16 & 33TVL67 & 33TWG71 \\
\hline \multicolumn{8}{|l|}{ imp } \\
\hline 32 TKQ82 & Q25 & 32TLQ47 & 2TLR33 & 2TLR58 & 32 TLR59 & 32TLR69 & 32TLR89 \\
\hline 32 TLS40 & 2 TLS60 & & & & & & \\
\hline 32 TLS83 & 32 TLS90 & 32TLS91 & & 32TMR09 & & & $32 \mathrm{TMS} 10$ \\
\hline 32TMS12 & TMS21 & TMS22 & TMS26 & MS31 & & & \\
\hline 32 TMS74 & & & & & & & \\
\hline 32 TNS65 & 67 & NS68 & $32 \mathrm{TN}$ & NS73 & JS75 & $S 76$ & 32 TNS83 \\
\hline 32 TNS87 & & & & & & & \\
\hline 32ТРТ32 & $32 \mathrm{VI}$ & & & & & & \\
\hline 33VUD71 & VWG72 & VWH24 & $\mathrm{H} 70$ & K64 & $\mathrm{J} 26$ & $\mathrm{~N} 93$ & VR88 \\
\hline 34UCF46 & & & & & & & \\
\hline 34VDM45 & 34VDM46 & 148 & & & & & \\
\hline 34VEM57 & & & & & & & \\
\hline 34VFM13 & 414 & & & & & & \\
\hline 34WDB85 & 395 & 53 & & & & & \\
\hline 35VLG77 & & & & & & & IH40 \\
\hline 35VMH62 & & & & & & & \\
\hline $35 \mathrm{VNJ} 68$ & K04 & & & & & & \\
\hline 35VNL99 & & & & & & & \\
\hline 35WLN91 & M75 & & & & & & \\
\hline 35WNM72 & & & & & & & \\
\hline 46UBU77 & 46UBU96 & A84 & & & & DA13 & 46UDA21 \\
\hline 46UDA22 & & & & & & & \\
\hline & & & & & & & \\
\hline 48TXU80 & & 48TYU21 & & & & & 48UXU27 \\
\hline 48UXU41 & & & & & & & \\
\hline \multicolumn{8}{|l|}{ nig } \\
\hline 29RMN00 & & & & & & & 29RPQ56 \\
\hline & & & & & & & 29SMC97 \\
\hline & & & & & & & 29SPB82 \\
\hline & & & & & & & 30 STB32 \\
\hline & & & & & & & \\
\hline & & & & & & & 30 SVG80 \\
\hline & & & & & & & 30SWG00 \\
\hline 30SWG77 & & & & & & & 30 SYH56 \\
\hline 30SYH57 & 30 SYJ27 & 30TTL92 & 30TTL95 & 30TUL09 & 30TUM00 & 30TUM41 & 30TUM52 \\
\hline 30TVK39 & 30TVM48 & & & & & 30TXK28 & 30ТХК66 \\
\hline & & & 30TXM98 & 30TYL46 & & 30TYN30 & 31SBC48 \\
\hline 31 SBC59 & 31 SCD41 & 31 TBE77 & 31 TBF55 & 31 TBG61 & 31 ТВН77 & 31TCF18 & 31TCF24 \\
\hline & & & & & & $31 \mathrm{TDH} 87$ & 31 TEG17 \\
\hline 31 TEG28 & 31 TEH00 & 31 TFJ11 & $31 \mathrm{TFJ} 44$ & $31 \mathrm{TFJ} 46$ & 31 TFJ54 & 31 TFJ63 & 31 TFJ67 \\
\hline 31TFJ69 & $31 \mathrm{TFJ} 75$ & 31 TFJ76 & $31 \mathrm{TFJ} 84$ & $31 \mathrm{TFJ} 85$ & 31 TFJ92 & 31 TFJ96 & 31TFK62 \\
\hline
\end{tabular}




\begin{tabular}{|c|c|c|c|c|c|c|c|}
\hline 31 TFK65 & 31TFL46 & 31TGJ21 & 32 SMD78 & 32 SMF78 & $32 \mathrm{TKN} 88$ & 32 ТКР74 & 32ТКР95 \\
\hline 32 TKS62 & 32TLN08 & 32 TLP10 & 32TLP11 & 32 TLP13 & 32 TLP23 & 32 TLP27 & 32 TLP28 \\
\hline 32 TLP33 & 32 TLP43 & 32 TLP75 & 32 TLP95 & 32TLQ03 & 32 TLR66 & 32 TLS50 & 32TLS51 \\
\hline 32 TLS71 & 32 TLS72 & 32 TLS81 & 32 TLS82 & 32 TLS83 & 32TLS91 & 32 TLS92 & 32 TLS93 \\
\hline 32TLT40 & 32 TMM80 & 32TMN71 & 32ТМР37 & 32ТМР59 & 32TMR09 & 32TMS02 & 32TMS03 \\
\hline 32TMS12 & 32 TMS22 & 32TNK45 & 32 TNK57 & $32 \mathrm{TNM} 13$ & 32 TNN22 & 32 TNQ81 & $33 S U C 10$ \\
\hline 33SWB08 & 33SWB28 & 33 SXD29 & 33TTG93 & 33TUF66 & 33TUL14 & 33TUL56 & 33TUL87 \\
\hline 33TUL93 & 33TVF32 & 33TVG06 & 33TVK39 & 33TVK76 & 33TWG74 & 33 TXF90 & 33TXJ11 \\
\hline 33 TXJ21 & 34SEF99 & & & & & & \\
\hline \multicolumn{8}{|l|}{ wol } \\
\hline 32 TMQ21 & 32TMQ23 & 32TMQ24 & 32TMQ42 & 33ТТН66 & 33TUG88 & 33TUG92 & 33TUG98 \\
\hline 33TUH05 & 33TUH06 & 33TVG02 & & & & & \\
\hline
\end{tabular}

\section{Appendix B}

Indicative map of the European biogeographical regions, 2005 (baseline map: CEEA, Copenhagen, 2007).

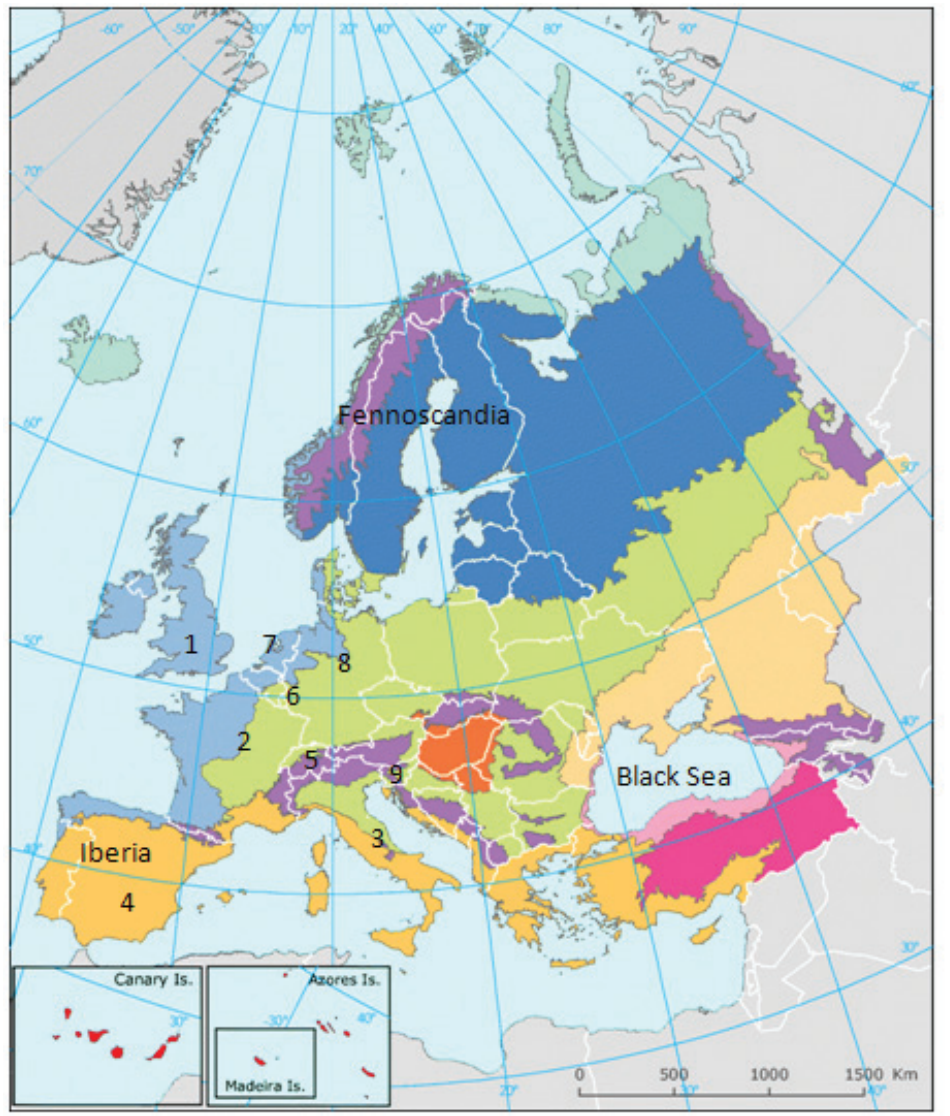

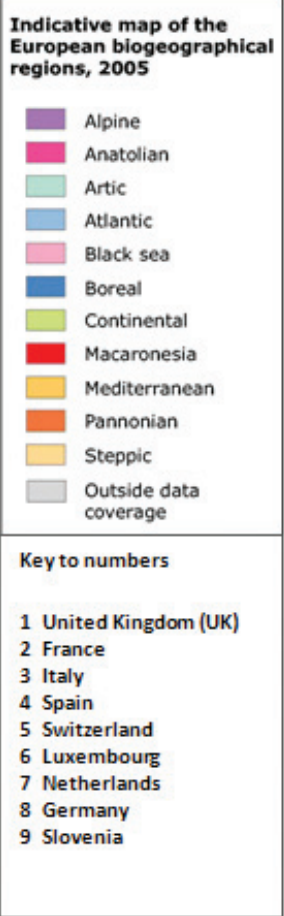

Baseline map (a) EEA, Copenhagen, 2007 